\title{
A global event with a regional character: the Early Toarcian Oceanic Anoxic Event in the Pindos Ocean (northern Peloponnese, Greece)
}

\author{
N. KAFOUSIA* $\uparrow$, V. KARAKITSIOS*, H. C. JENKYNS $\ddagger$ E. MATTIOLI§ \\ *Department of Geology and Geoenvironment, National University of Athens, Panepistimiopolis, 15784 Athens, Greece \\ tDepartment of Earth Sciences, University of Oxford, South Parks Road, Oxford OX1 3AN, UK \\ §Université Claude Bernard Lyon I, UMR 5125, CNRS, PaléoEnvironnements et PaléobioSphère, Département des \\ Sciences de la Terre, 2 rue Dubois, 69622 Villeurbanne, France
}

(Received 3 March 2010; accepted 3 December 2010)

\begin{abstract}
The Early Toarcian (Early Jurassic, c. $183 \mathrm{Ma}$ ) was characterized by an Oceanic Anoxic Event (T-OAE), primarily identified by the presence of globally distributed approximately coeval black organic-rich shales. This event corresponded with relatively high marine temperatures, mass extinction, and both positive and negative carbon-isotope excursions. Because most studies of the T-OAE have taken place in northern European and Tethyan palaeogeographic domains, there is considerable controversy as to the regional or global character of this event. Here, we present the first high-resolution integrated chemostratigraphic (carbonate, organic carbon, $\delta^{13} \mathrm{C}_{\text {carb }}, \delta^{13} \mathrm{C}_{\text {org }}$ ) and biostratigraphic (calcareous nannofossil) records from the Kastelli Pelites cropping out in the Pindos Zone, western Greece. During the Mesozoic, the Pindos Zone was a deep-sea oceanmargin basin, which formed in mid-Triassic times along the northeast passive margin of Apulia. In two sections through the Kastelli Pelites, the chemostratigraphic and biostratigraphic (nannofossil) signatures of the most organic-rich facies are identified as correlative with the Lower Toarcian, tenuicostatum/polymorphum-falciferum/serpentinum/levisoni ammonite zones, indicating that these sediments record the T-OAE. Both sections also display the characteristic negative carbon-isotope excursion in organic matter and carbonate. This occurrence reinforces the global significance of the Early Toarcian Oceanic Anoxic Event.
\end{abstract}

Keywords: Toarcian Oceanic Anoxic Event, Pindos Zone, carbon isotopes, Greece, Kastelli Pelites.

\section{Introduction}

The Early Toarcian (c. $183 \mathrm{Ma}$ ) was associated with global warming (Bailey et al. 2003; Jenkyns, 2003), mass extinction (Little \& Benton, 1995; Wignall, Newton \& Little, 2005) and a globally increased rate of organic carbon burial attributed to an Oceanic Anoxic Event (OAE) (Jenkyns, 1985, 1988, 2010; Karakitsios, 1995; Rigakis \& Karakitsios, 1998; Jenkyns, Gröcke \& Hesselbo, 2001; Karakitsios et al. 2004, 2007). The Toarcian OAE (T-OAE) coincides with an overall positive and interposed negative carbon-isotope excursion that has been recorded in marine organic matter, pelagic and shallow-water marine carbonates, brachiopods and fossil wood (Hesselbo et al. 2000, 2007; Schouten et al. 2000; Röhl et al. 2001; Kemp et al. 2005; van Breugel et al. 2006; Suan et al. 2008, 2010; Woodfine et al. 2008; Hermoso et al. 2009; Sabatino et al. 2009). To date, most research has concentrated on N European and Tethyan palaeogeographic environments, representing shelf seas and drowned carbonate platforms on foundered continental margins (Bernoulli \& Jenkyns, 1974, 2009). Thus, an ongoing vigorous debate exists as to whether the recorded patterns of Toarcian carbon burial and carbon-isotope evolution represent only

$\dagger$ Author for correspondence: nkafousia@geol.uoa.gr processes occurring within these relatively restricted palaeogeographic marine environments or whether they were truly global in character (e.g. Küspert, 1982; van der Schootbrugge et al. 2005; Wignall et al. 2006; Hesselbo et al. 2007; Svensen et al. 2007; Suan et al. 2008). Those pointing to local factors suggest overturning of a stratified water column rich in $\mathrm{CO}_{2}$ from the oxidation of organic matter; those suggesting global control suggest introduction of isotopically light carbon into the ocean-atmosphere system from dissociation of gas hydrates or hydrothermal venting of greenhouse gases. Certainly, the recent recognition of the T-OAE in Argentina suggests the impact of this phenomenon was not confined to the northern hemisphere (Al-Suwaidi et al. 2010).

In Greece, only limited geochemical data are available for the T-OAE (Jenkyns, 1988). During the period from the Triassic to the Late Cretaceous, the external Hellenides (western Greece) constituted part of the southern Tethyan margin (Fig. 1), where siliceous and organic carbon-rich sediments were commonly associated facies (Bernoulli \& Renz, 1970; Karakitsios, 1995; de Wever \& Baudin, 1996). The Ionian and Pindos zones of western Greece (Fig. 2) expose such basinal, thrust-imbricated sediments that document continental (Ionian Zone) and continent-ocean-margin basinal pelagic sequences (Pindos Zone). 


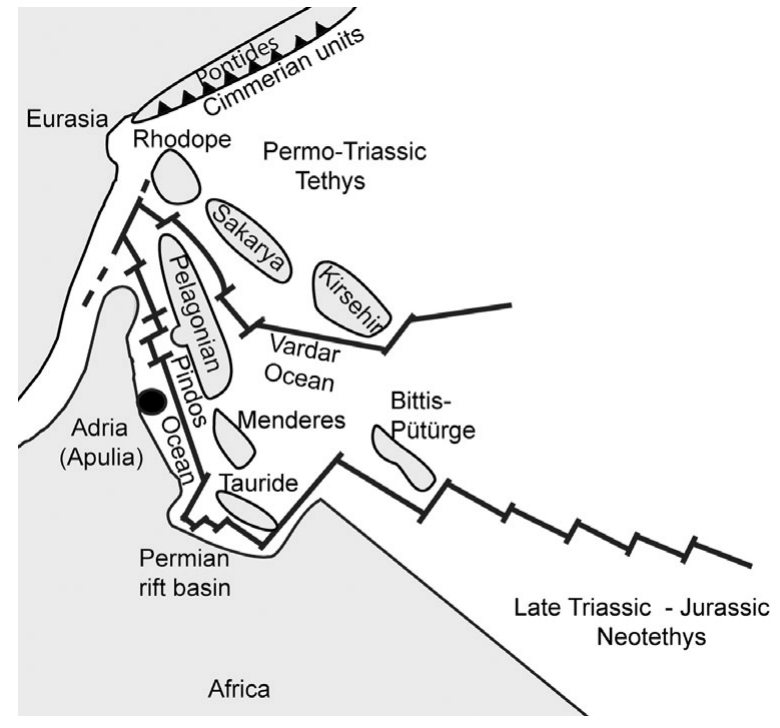

Figure 1. Early Jurassic palaeogeography of the western Tethys Ocean (based on Clift, 1992; Dercourt, Ricou \& Vriellynck, 1993; Channell \& Kozur, 1997; Degnan \& Robertson, 1998; Pe-Piper, 1998). The approximate position of the study area is illustrated by the black circle. The stable segment of Adria is approximately the size of the area now occupied by the Adriatic Sea, parts of eastern Italy, the Southern Alps and Istria. do western edge of the Pindos Ocean. Integrated chemostratigraphic and biostratigraphic studies of the Kastelli Pelites, here unambiguously indentified as deposited during the Early Toarcian OAE, strongly reinforce the global character of the T-OAE.

\section{Geological setting and stratigraphy}

The Pindos Zone (Fig. 2) exposes an imbricate thrust belt with allochthonous Mesozoic to Tertiary sedimentary rocks of deep-water facies. The zone extends into Albania and former Yugoslavia (Dédé et al. 1976; Robertson \& Karamata, 1994) as well as into Crete (Bonneau, 1984), Rhodes (Aubouin et al. 1976) and Turkey (Bernoulli, de Graciansky \& Monod, 1974; Argyriadis et al. 1980). The sediments of the Pindos Zone originate from an elongate remnant ocean basin that formed in mid-Triassic time along the northeastern passive margin of Apulia between the extensive Gavrovo-Tripolis platform in the present west and the Pelagonian continental block in the east (including also the isolated Parnassos Platform in its western portion). Continental collision in the Aegean area has produced a collage of microcontinental blocks, which were accreted to the active margin of Eurasia in early Tertiary times. Observations on the Greek mainland as well as on the island of Crete confirm that the eastern basal rocks of the Pindos Zone and the southwestern end of the Pelagonian continental terrane were rifted from Gondwana in mid-Triassic times (De Wever, 1976; Bonneau, 1982; Clift, 1992; Degnan \& Robertson, 1998; Pe-Piper, 1998). By Early Jurassic

86

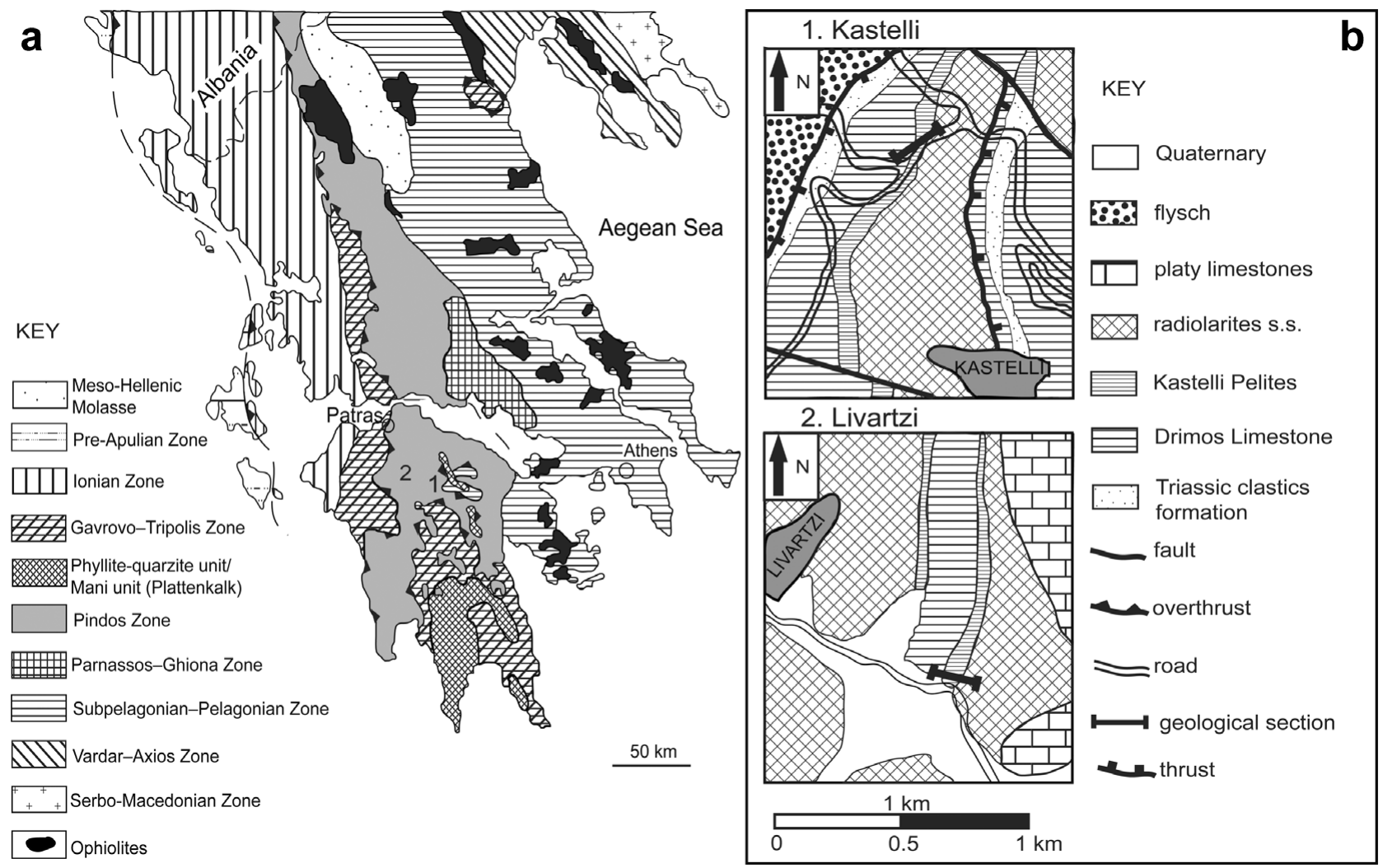

Figure 2. (a) Simplified geological map with the main tectonostratigraphic zones of the Hellenides. (b) Geological map of Kastelli section (above) and Livartzi section (below). 
time at the latest (Fig. 1), actively spreading oceanic basins had opened in both the Pindos and the Vardar Zones on either side of the Pelagonian continental block (De Wever, 1976; Bonneau, 1982; Robertson et al. 1991; Clift, 1992; Lefèvre et al. 1993; Pe-Piper \& Hatzipanagiotou, 1993; Degnan \& Robertson, 1998; Pe-Piper, 1998). The evidence indicating the oceanic character of the Pindos Basin is summarized by Degnan \& Robertson (1998). The western Pindos Ocean separated Pelagonia from Apulia; the eastern Vardar Ocean separated Pelagonia from the Serbomacedonia and Sarakya microcontinents. Later Mesozoic and Cenozoic convergence resulted in the nappe structure of the Hellenide Orogen and the tectonic dismemberment of the Permian-Triassic rift-related igneous rocks. The amount of orogen-parallel transport during closure of the Pindos and Vardar oceans is uncertain, but most authors argue that it was not large (Robertson et al. 1991; Wooler, Smith \& White, 1992). The Pindos Zone of western Greece is exceptional since it was deformed into a regular series of thrust sheets during its emplacement, with a minimum of disruption. The present-day westward-vergent fold and thrust sheets have not been affected by major back-thrusting or outof-sequence thrusting (Degnan \& Robertson, 1998).

The sedimentary successions of the Pindos Zone comprise deep-water carbonate, siliciclastic and siliceous rocks, ranging in age from Late Triassic to Eocene (Fleury, 1980; Degnan \& Robertson, 1998).

\section{Field observations}

\section{3.a. Kastelli section}

The Kastelli section $\left(37^{\circ} 54^{\prime} \mathrm{N}, 22^{\circ} 02^{\prime} \mathrm{E}\right)$ is located about $200 \mathrm{~m}$ westwards of the junction of the Kalavrita-Klitoria and Kalavrita-Aroania roads. In this section, the outcrop is of excellent quality and illustrates, in stratigraphic continuity, the Drimos Limestone Formation, the Kastelli Pelites and the radiolarites sensu stricto. The outcrops correspond to the eastern more distal part of the Pindos western margin. From the bottom to top the following lithological units are observed:

(i) The Drimos Limestone Formation, which comprises sediments some $100 \mathrm{~m}$ thick. The lower part is $35 \mathrm{~m}$ thick and is developed as an alternation of limestones, with filaments (thin-shelled bivalves), and green pelites. This unit, which is chert-bearing, is dated as Norian, at a point about $300 \mathrm{~m}$ southwest of this section (J. M. Flament, unpub. Ph.D. thesis, Univ. Lille, 1973). A radiolarian cherty member, about $10 \mathrm{~m}$ thick, divides the lower from the upper part, which comprises mainly limestones attaining some $60 \mathrm{~m}$ in thickness. A precise age determination in this upper part is not possible with the observed faunas, because they are represented only by some reworked algae and Foraminifera (e.g. Thaumatoporella sp. and Textulariida, respectively). (ii) The Kastelli Pelites, comprising sediments about $35 \mathrm{~m}$ thick. The first $8 \mathrm{~m}$ consists of a succession of thin-layered $(5-10 \mathrm{~cm})$ marly limestones alternating with mainly grey marls (a limestone layer with chert nodules is interbedded in the lower part of the succession). The sequence continues with 3-4 m of red marls, marly clays and clays with some intercalations of marly limestone. Above, there follows some $6 \mathrm{~m}$ of mainly marly limestones and marls containing rare black chert layers. In thin-sections of the marly limestones, badly preserved Foraminifera are observed. The succession finishes with $5 \mathrm{~m}$ of marly limestones and red marls, cherty at the top. These cherts indicate a passage into the stratigraphically overlying radiolarites sensu stricto.

\section{3.b. Livartzi section}

The Livartzi section $\left(37^{\circ} 55^{\prime} \mathrm{N}, 21^{\circ} 55^{\prime} \mathrm{E}\right)$ is located north of the Tripotama-Kalavrita road by the turning towards Livartzi village. The outcrop corresponds to the western (closer to the Tripolis Platform) part of the Pindos margin. Here the Kastelli Pelites are thinner (20 $\mathrm{m}$ thick) than those of the Kastelli section itself (35 $\mathrm{m}$ thick).

The sampling started in the upper $6 \mathrm{~m}$ of the Drimos Limestone Formation, comprising thin layers of marly limestone. Quaternary sediments cover the first $3 \mathrm{~m}$ of Kastelli Pelites. After this exposure gap, there follows a $1 \mathrm{~m}$ marly limestone bed, and the section continues with the typical Kastelli Pelites Formation, as described for the type locality.

\section{Methods}

In total, 325 bulk sediment samples were collected from the two sections (191 from Kastelli and 134 from Livartzi). The collected samples were powdered and analysed for weight per cent total organic carbon and the equivalent amount of $\mathrm{CaCO}_{3}$ using a Strohlein Coulomat 702 analyser (details in Jenkyns, 1988), for carbonate carbon and oxygen isotopes using a VG Isogas Prism II mass spectrometer (details in Jenkyns, Gale \& Corfield, 1994) and for organic-matter carbon and oxygen isotopes using a Europa Scientific Limited CN biological sample converter connected to a 20-20 stable-isotope gas-ratio mass spectrometer (details in Jenkyns et al. 2007). All the above analyses were undertaken in the Department of Earth Sciences and Research Laboratory for Archaeology in the University of Oxford. Results for both sections are given in Tables $\mathrm{A} 1$ and $\mathrm{A} 2$ in the online Appendix at http://journals.cambridge.org/geo.

A set of 27 samples from Kastelli and 28 from Livartzi was investigated for its content of calcareous nannofossils. Smear-slides were prepared from the powdered rock according to the technique described in Bown \& Young (1998), then analysed in an optical polarizing Leitz microscope at $\times 1250$. Nannofossils 


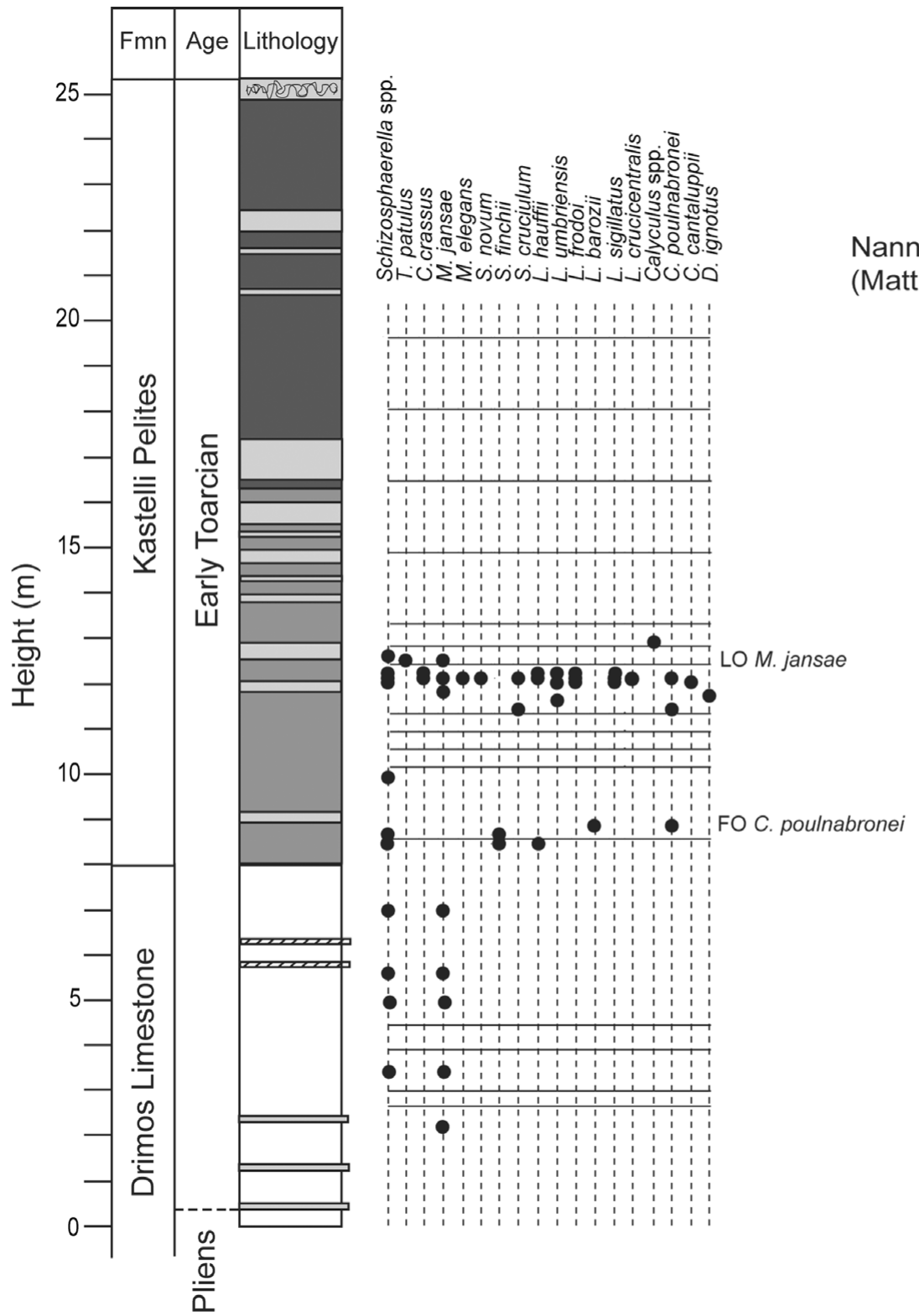

Nannofossil Zones
(Mattioli \& Erba, 1999)

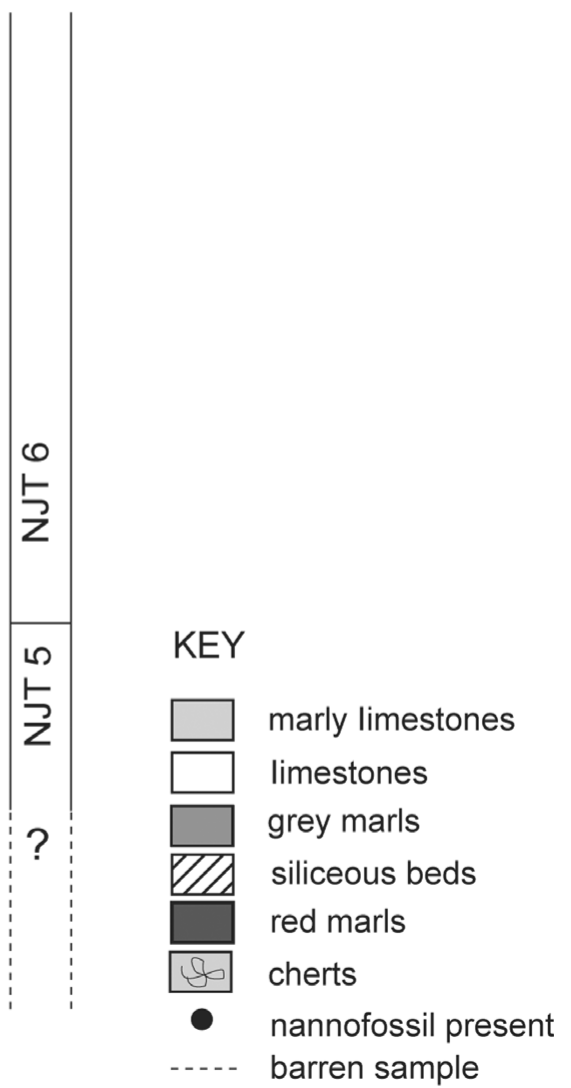

Figure 3. Lithological column and biostratigraphical data from the Kastelli section. Nannofossil zones after Mattioli \& Erba (1999).

were counted for each sample in a surface area of the slide varying between 1 and $2 \mathrm{~cm}^{2}$.

\section{Results}

\section{5.a. Biostratigraphy}

There are very few data concerning the age of the Kastelli Pelites, the lack of ammonites indicating that the sequence was deposited below the aragonite compensation depth. Lyberis, Chotin \& Doubinger (1980) attributed the unit to the Late Pliensbachian/Toarcian, comparing the palynological associations with those of the Vicentin Alps. Nevertheless, the only precise data are referred to by Fleury (1980) and de Wever \& Origlia-Devos (1982), who suggest an Aalenian age for the top of the Kastelli Pelites unit. Fleury's (1980) data are based on the presence of Meyendorffina (Lucasella) cayeuxi (Lucas) in a limestone layer at the top of Kastelli Pelites in the Karpenission region (central Greece); and de Wever \& Origlia-Devos's (1982) data are based on Foraminifera faunas from the Peloponnese. Based on general biostratigraphic and chemostratigraphic considerations, Jenkyns (1988) suggested that the Kastelli Pelites were correlative with other black shales in Greece (in the Ionian Zone) and were formed during the T-OAE.

We undertook detailed biostratigraphical analyses of calcareous nannofossils in an effort to improve and expand the biostratigraphical resolution from previous studies. The nannofossil distribution is summarized in Figures 3 and 4.

\section{5.a.1. Kastelli section}

Samples were taken from the limestones at the top of the Drimos Limestone Formation, as well as from the lower to middle part of the Kastelli Pelites for 


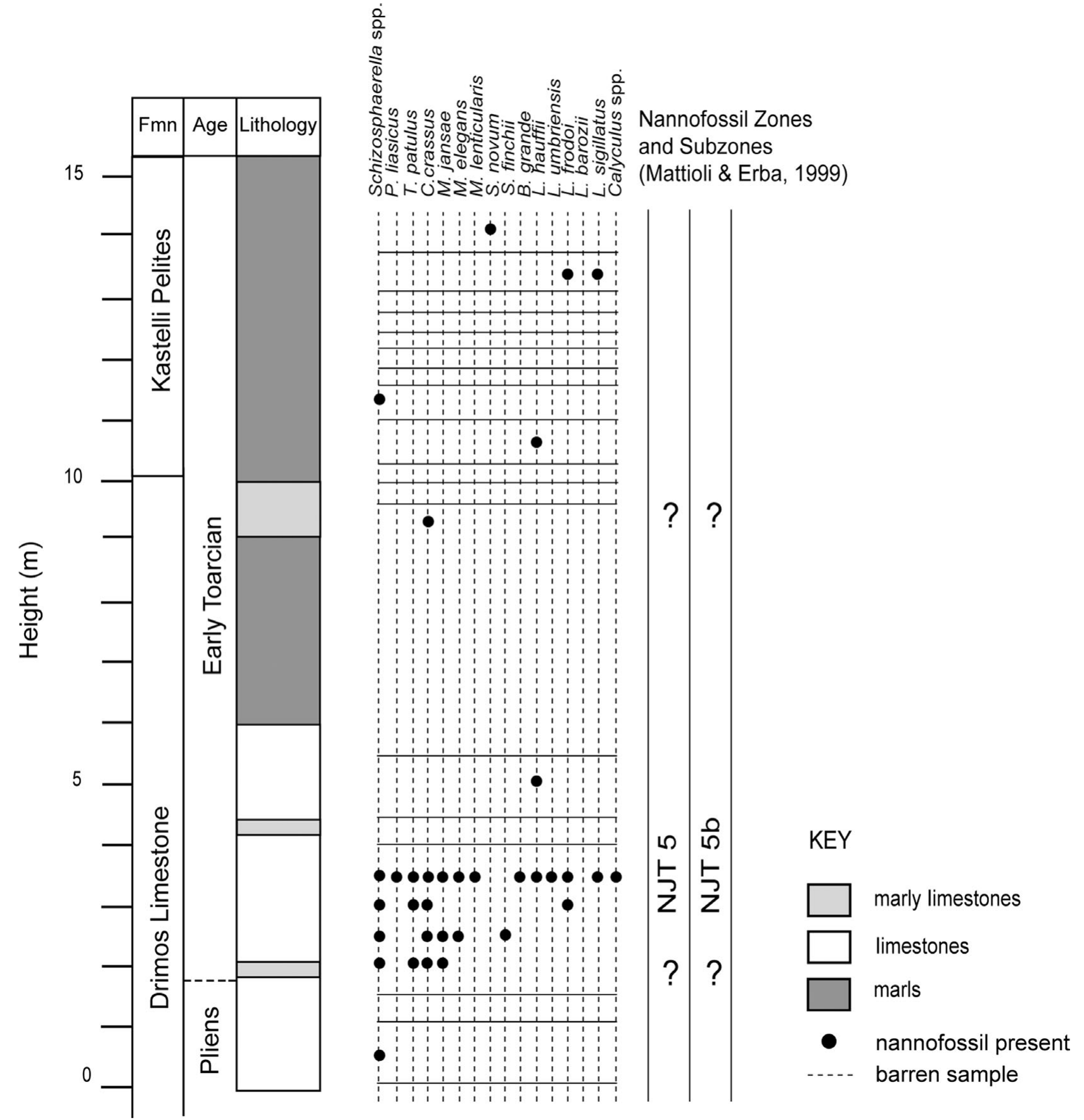

Figure 4. Lithological column and biostratigraphical data from the Livartzi section. Nannofossil zones after Mattioli \& Erba (1999).

a thickness of about $20 \mathrm{~m}$. Twelve samples were barren of nannofossils, and the rest contained very few specimens. The assemblage is represented by rare Schizosphaerella spp., Mitrolithus jansae and M. elegans, Calyculus spp., Similiscutum cruciulum, S. finchii and S. novum, Tubirhabdus patulus, Crepidolithus crassus, and various species of the genus Lotharingius, including the zonal marker L. hauffii. This assemblage allows us to identify the NJT 5 nannofossil Zone (Late Pliensbachian to Early Toarcian). Specimens belonging to the Carinolithus genus, namely $C$. poulnabronei and $C$. cantaluppii, were recorded discontinuously starting from sample 34 . This occurrence can be used at Kastelli to identify the NJT 6 nannofossil Zone. The last occurrence of Mitrolithus jansae was observed in sample $71(12.5 \mathrm{~m})$. A single specimen of Discorhabdus ignotus was encountered in sample $63(12 \mathrm{~m})$. The first occurrence of this species is fixed at the tenuicostatum/serpentinum zonal boundary in central Italy (Mattioli \& Erba, 1999), where it is considered to mark the end of the Early Toarcian OAE (Bucefalo Palliani \& Mattioli, 1998; Mattioli et al. 2004), although in some areas an earlier occurrence of D. ignotus is recorded (Mattioli et al. 2008; Bodin et al. 2010).

\section{5.a.2. Livartzi section}

Only 14 samples of the Livartzi section were found to contain calcareous nannofossils. The productive 

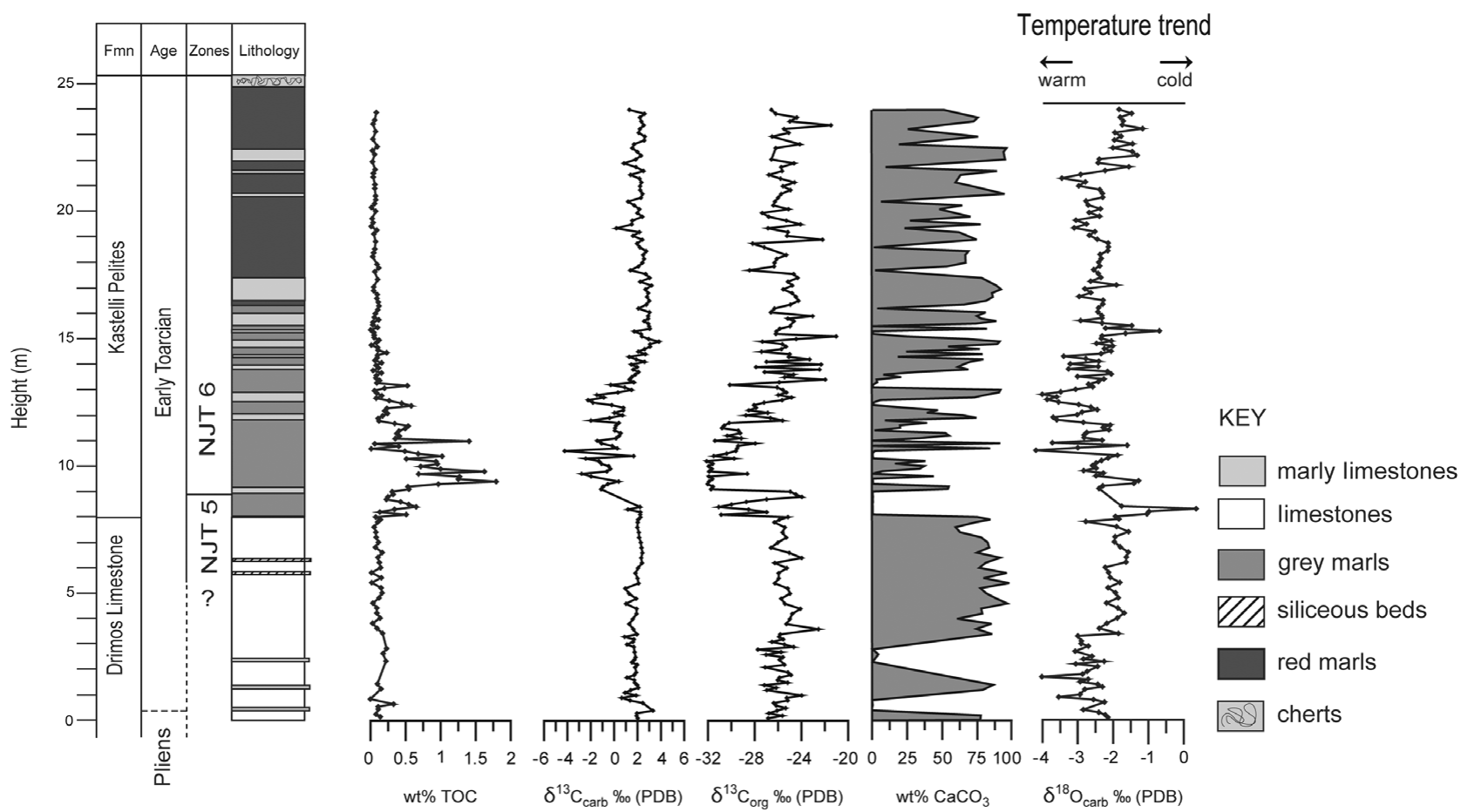

Figure 5. Lithostratigraphical log, bulk TOC, stable-isotope $(\mathrm{C}, \mathrm{O})$ and $\mathrm{wt} \% \mathrm{CaCO}_{3}$ profiles through the Kastelli section. For a colour version of this figure see online Appendix at http://journals.cambridge.org/geo.

samples show assemblages similar to those of the Kastelli section with poorly preserved and rare nannofossils. The interval between samples 11 and 36 (from 1.1 to $3.6 \mathrm{~m}$ ) represents an exception, because samples are richer, with common Schizosphaerella and $M$. jansae. The stratigraphically highest specimen of $M$. jansae is recorded in sample $36(3.6 \mathrm{~m})$. However, we cannot confidently define this datum level as a last occurrence because the samples studied in the interval above are barren of nannofossils. This assemblage, and the presence in the assemblage of $L$. sigillatus, allows attribution of this interval to the NJT $5 \mathrm{~b}$ nannofossil Subzone (uppermost Pliensbachian to lowermost Toarcian).

\section{5.b. Chemostratigraphy}

\section{5.b.1. Kastelli section}

5.b.1.a. Organic carbon and carbonate profiles Chemostratigraphic data are illustrated in Figure 5. The total organic carbon (TOC) values are very low and stable in the lower part of the section where background values are in the range $0.10-0.20 \mathrm{wt} \%$. After the lowest $7.5 \mathrm{~m}$, the TOC values begin to rise gradually for $1.5 \mathrm{~m}$ defining a positive excursion to reach a maximum value of $1.79 \mathrm{wt} \%$. At the top of this interval, values return to background levels.

The carbonate values do not follow any particular trend nor do they respond to the excursion. Up to the level where the TOC excursion begins, the percentage of $\mathrm{CaCO}_{3}$ in the bulk rock fluctuates between 60 and $100 \%$. When the excursion begins, there is a sudden drop to reach values lower than $10 \%$; following that, values start to rise again until the top of the studied section, with relative minima being attained every few metres. A similar pattern is seen in other Tethyan pelagic sections recording the T-OAE (e.g. Sabatino et al. 2009).

5.b.1.b. Stable-isotope (carbon and oxygen) profiles The carbon- and oxygen-isotope values in carbonate and the TOC of bulk rock are reported in Figure 5. The bulk carbonate carbon-isotope values record a small positive followed by a negative excursion in the lowest metre of the section. Above this small disturbance, values are very stable within the next $7.5 \mathrm{~m}$ of the section, with background values of $2 \%$. Thereafter, $\delta^{13} \mathrm{C}_{\text {carb }}$ values begin to fall irregularly, reaching a minimum of $-5 \%$. The negative excursion extends over the next $5 \mathrm{~m}$ before recovery takes place and background values of $\sim 2 \%$ are restored. What is remarkable is the polarity between the TOC profile and the carbonate carbon-isotope profile, with the two curves appearing as approximate mirror images of one another. The stratigraphical coincidence between the negative carbonisotope excursion and relative TOC maximum is also observed in Toarcian black shales from northwestern Europe and central Italy (Jenkyns \& Clayton, 1997; Jenkyns et al. 2002; Mattioli et al. 2004).

The organic carbon-isotope profile is slightly different from that of $\delta^{13} \mathrm{C}_{\text {carb }}$. The first shift is recorded in the interval 8 to $9 \mathrm{~m}$ and records a drop from $-25.15 \%$ to $-31.1 \%$; following this excursion, values return to $-24.95 \%$. Above this level, values drop again, to $-32.1 \%$, and remain low for approximately $2.5 \mathrm{~m}$. Stratigraphically higher in the section, values become 
Kastelli

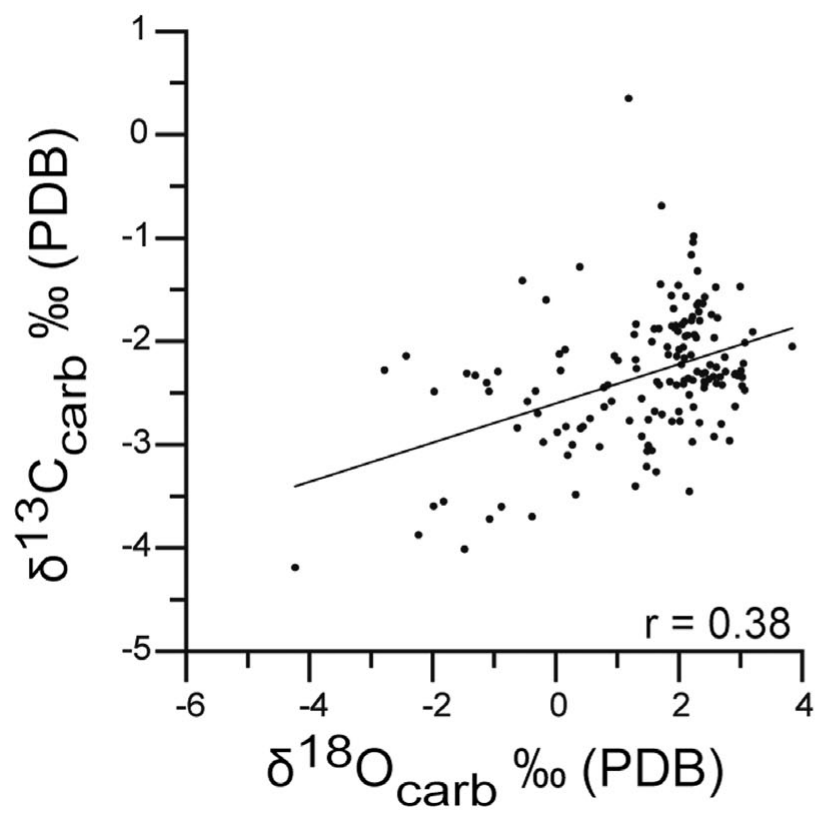

Livartzi

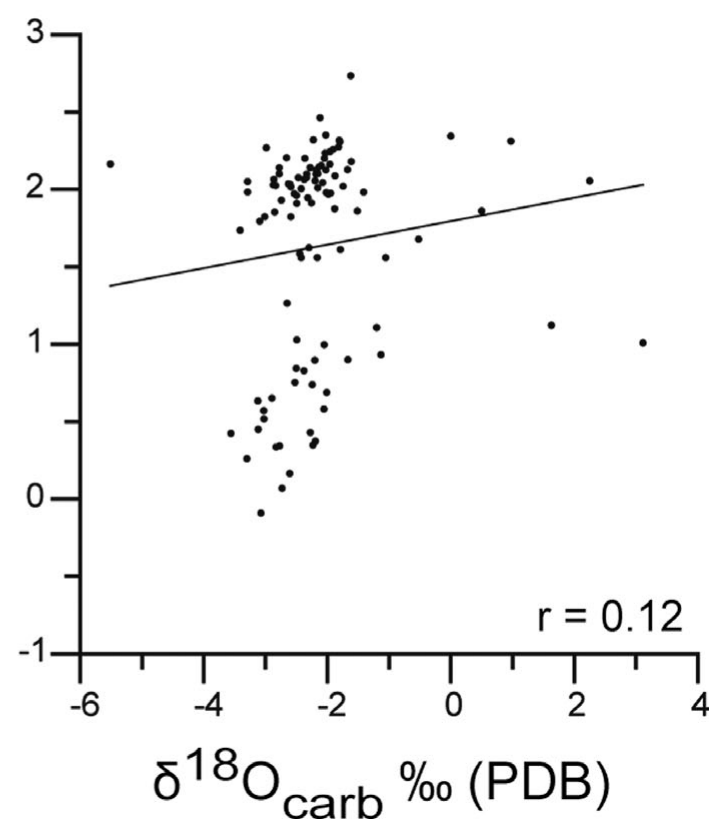

Figure 6. Cross-plot of $\delta^{13} \mathrm{C}_{\text {carb }}$ and $\delta^{18} \mathrm{O}_{\text {carb }}$ data from the Kastelli and Livartzi sections. For a colour version of this figure see online Appendix at http://journals.cambridge.org/geo.

heavier and fluctuate around a background value of $-25 \%$.

Oxygen-isotope values are generally in the range of $-2 \%$ (Fig. 5), which is a typical value for $\delta^{18} \mathrm{O}$ in Tethyan Pliensbachian/Toarcian boundary carbonates, boreal belemnites and brachiopods (Jenkyns \& Clayton, 1986; McArthur et al. 2000; Jenkyns et al. 2002; Rosales, Robles \& Quesada, 2004; Suan et al. 2008). At the $8.5 \mathrm{~m}$ level of the section, there is a positive spike of about $2 \%$, above which there is a shift towards lighter values. The lighter values correspond stratigraphically to the negative excursion of the carbon isotopes. $\delta^{18} \mathrm{O}$ values remain low and do not return to $-2 \%$ until the $21.5 \mathrm{~m}$ level of the section. To what extent these carbonates record primary palaeotemperature signals and to what extent they have been modified by diagenesis is not known, but some primary signature is assumed, given the correlation with palaeotemperature trends established elsewhere in Europe (Bailey et al. 2003; Jenkyns, 2003). The cross-plot of $\delta^{13} \mathrm{C}_{\text {carb }}$ and $\delta^{18} \mathrm{O}_{\text {carb }}$ values (Fig. 6) gives a Pearson's correlation coefficient value $r$ of 0.38 , which implies moderate correlation between oxygen- and carbon-isotopic values. If it is assumed that an increase in temperature (lowering $\delta^{18} \mathrm{O}$ values) would follow from an introduction of isotopically light carbon in the ocean-atmosphere system (as $\mathrm{CH}_{4}$ or $\mathrm{CO}_{2}$ ), some correlation between $\delta^{18} \mathrm{O}$ and $\delta^{13} \mathrm{C}$ would be expected (e.g. Jenkyns, 2003).

\section{5.b.2. Livartzi section}

5.b.2.a. Organic carbon and carbonate profiles The TOC values and the percentage of $\mathrm{CaCO}_{3}$ in bulk rock are reported in Figure 7. In this section, the TOC values are even lower than those at Kastelli, ranging from undetectable to $0.6 \mathrm{wt} \%$. Nevertheless, an interval of relatively high values is located between the 9.6 and $11.2 \mathrm{~m}$ levels. Above and below that interval, TOC values are close to zero. The $\mathrm{CaCO}_{3}$ content of the section is in general relatively high $(>70 \%)$, except for levels higher than that of the TOC maximum, where $\mathrm{CaCO}_{3}$ values drop to less than $10 \%$.

5.b.2.b. Stable-isotope (carbon and oxygen) profiles The carbonate carbon-isotope and the organic carbonisotope stratigraphy of the Livartzi section are shown in Figure 7. This section has two distinct negative excursions. The $\delta^{13} \mathrm{C}_{\text {carb }}$ in the Drimos Limestone Formation is very stable and constant at $\sim 2 \%$. Above the $3 \mathrm{~m}$ sampling gap, values drop until they reach a minimum of $-0.09 \%$, then remain low for $\sim 1.5 \mathrm{~m}$. Thereafter follows the second negative excursion that extends over a greater thickness of section $(\sim 2 \mathrm{~m})$ but only drops to $0.45 \%$. Towards the top of the section, $\delta^{13} \mathrm{C}_{\text {carb }}$ values become higher.

The organic carbon-isotope profile approximately tracks the carbonate carbon-isotope profile, although there are differences. The $\delta^{13} \mathrm{C}_{\text {org }}$ signal in the limestones of the lower part of the section shows scattered data points, probably because only isotopically variable refractory carbon is present, given the very low TOC values. Stratigraphically higher, just after the gap, the isotopic values are low, reaching the minimum value of $-31.85 \%$ o. The values remain low for $\sim 1.5 \mathrm{~m}$. Higher in the section there is an increase of $8.5 \%$, above which values begin to fall again through the rest of 

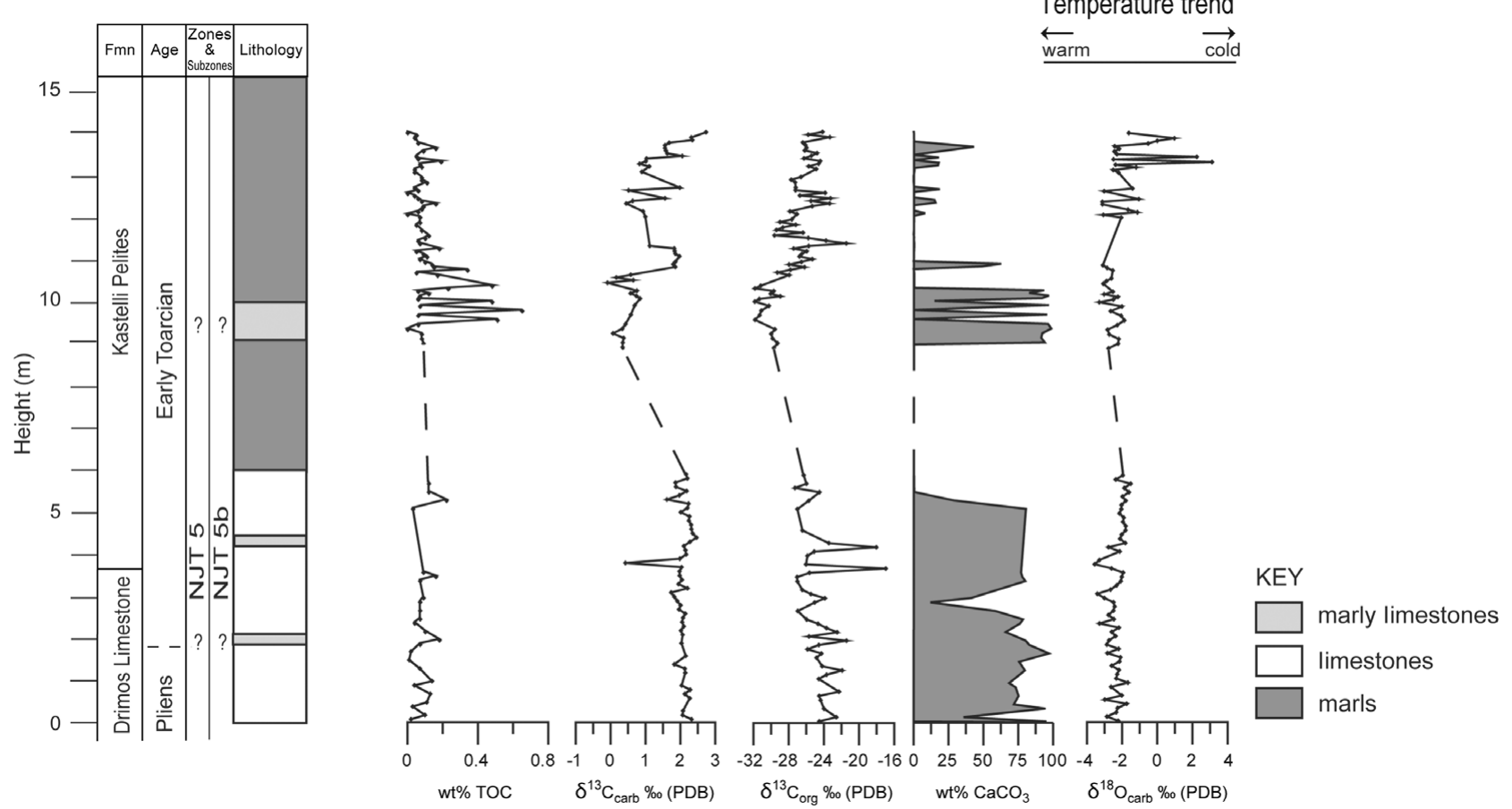

Figure 7. Lithostratigraphical log, bulk TOC, stable-isotope $(\mathrm{C}, \mathrm{O})$ and $\mathrm{wt} \% \mathrm{CaCO}_{3}$ profiles through the Livartzi section. The dashed line represents a sampling gap. For a colour version of this figure see online Appendix at http://journals.cambridge.org/geo.

the section. In the upper part of the section the $\delta^{13} \mathrm{C}_{\text {org }}$ values fluctuate around $-25 \%$.

Oxygen-isotope values fluctuate in this section also around $-2 \%$ o (Fig. 7). There is a small negative spike of about $1 \%$ at the level of the first carbonisotope negative excursion. Higher in the section, around the level of the second carbon-isotope negative excursion, the $\delta^{18} \mathrm{O}$ values become heavier, reaching values up to $\sim 4 \%$. The latter values are relatively high in comparison with other Tethyan Toarcian values. Moreover, as shown in Figure 6, the Pearson's correlation coefficient value of $\delta^{13} \mathrm{C}_{\text {carb }}$ and $\delta^{18} \mathrm{O}_{\text {carb }}$ from this section is 0.12 , which corresponds to a low degree of correlation between the isotopic values. Given the considerable difference between this and the Kastelli section, it is apparent that the $\delta^{18} \mathrm{O}$ values have been modified by diagenesis and do not record a primary isotopic record.

\section{Discussion}

\section{6.a. New biostratigraphic data based on calcareous nannofossils}

In spite of the paucity of calcareous nannofossil assemblages recorded in the two studied sections, some significant biostratigraphic results are presented in this work that allow direct dating of the carbon-isotope curves from Kastelli and Livartzi in addition to correlation with biostratigraphically welldated $\delta^{13} \mathrm{C}$ records from elsewhere. Although the standard chronostratigraphy of the Jurassic is based upon ammonite biostratigraphy, an increasing number of works present effective correlation of the Early
Toarcian negative isotope excursion (CIE) across the western Tethys based upon the ranges of calcareous nannofossils (Bucefalo Palliani, Mattioli \& Riding, 2002; Mattioli et al. 2004, 2008; Tremolada, van de Schootbrugge \& Erba, 2005; Mailliot et al. 2006, 2007; Bodin et al. 2010). In fact, the recognition of the NJT 6 nannofossil Zone in the Kastelli section allows unambiguous referral of the main negative CIE recorded in the Pindos Zone to the Early Toarcian and allows correlation with comparable phenomena associated with the Early Toarcian OAE in other NW European areas (Tremolada, van de Schootbrugge \& Erba, 2005; Mattioli et al. 2008) as well as a section in $\mathrm{N}$ Africa (Bodin et al. 2010).

A preceding negative excursion of $2 \%$ below the main carbon-isotope excursion has been recorded in Peniche (Portugal) and constitutes a chemostratigraphic marker for the Pliensbachian/Toarcian boundary (Hesselbo et al. 2007). In the Kastelli section, the carbonate carbon-isotope profile starts with a positive excursion of $\sim 1 \%$, and follows with a negative excursion of the same range. This negative excursion is not clearly dated by calcareous nannofossils in the Kastelli section, but it lies just below an interval assigned to the NJT 5 Zone, spanning the Late Pliensbachian-Early Toarcian interval. This negative excursion resembles those also observed at the stage boundary in Yorkshire (NE England), Valdorbia, (Marche-Umbria, Italy) and the High Atlas of Morocco, as recorded by Sabatino et al. (2009), Littler, Hesselbo \& Jenkyns (2010) and Bodin et al. (2010). Given the occurrence of this feature in the Pindos Zone, this isotopic feature, as proposed by Hesselbo et al. (2007) as at least a regional marker, is likely be of global significance. 


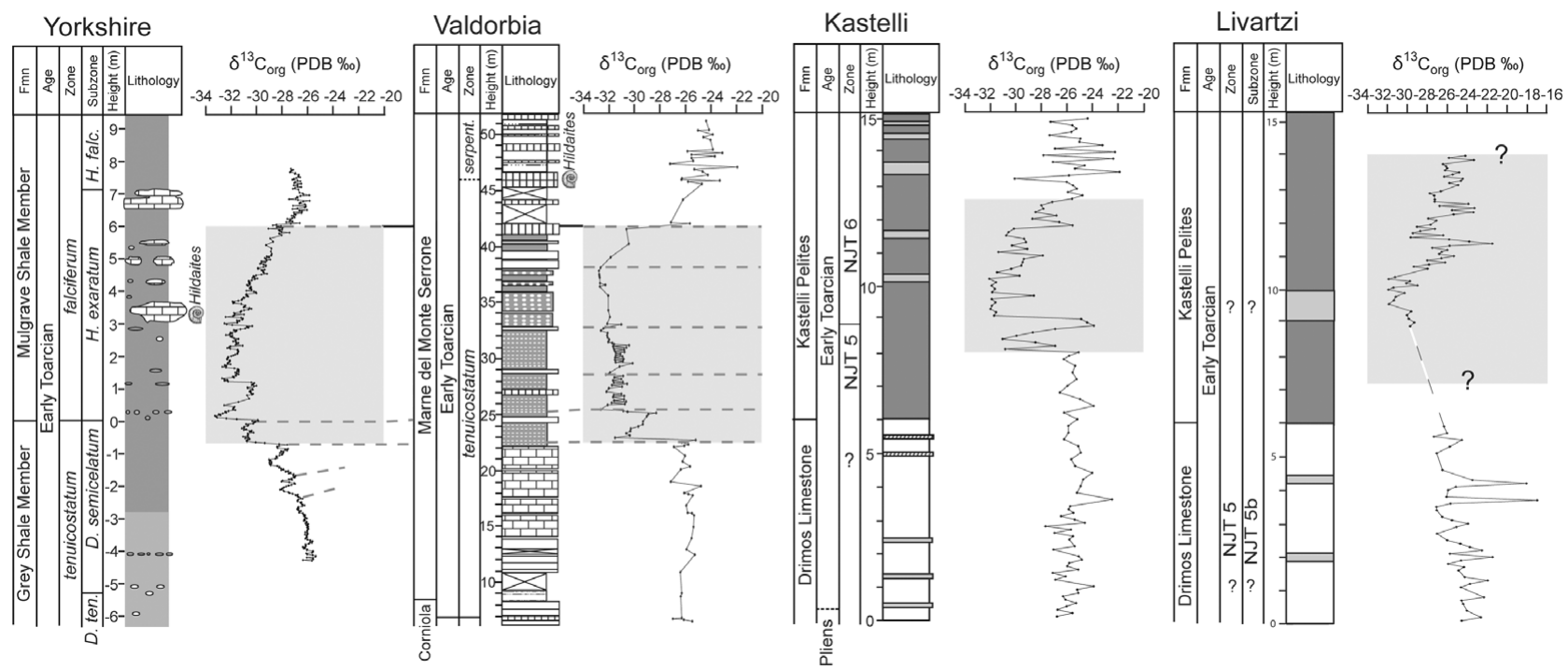

Figure 8. Comparison between the $\delta^{13} \mathrm{C}_{\mathrm{org}}$ data from Yorkshire, UK (Kemp et al. 2005), Valdorbia, Italy (Sabatino et al. 2009), and Kastelli and Livartzi, Greece. For a colour version of this figure see online Appendix at http://journals.cambridge.org/geo.

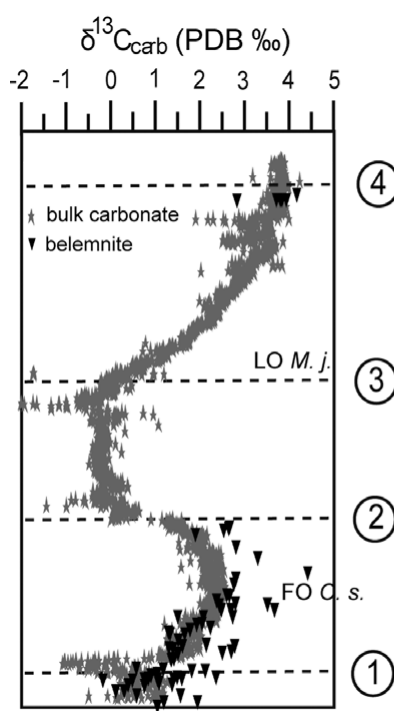

Peniche, Portugal

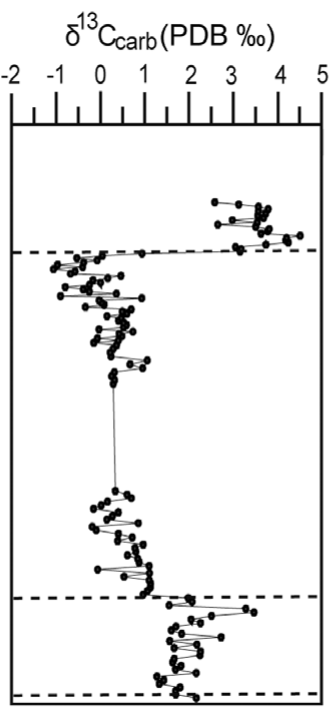

Valdorbia, Italy

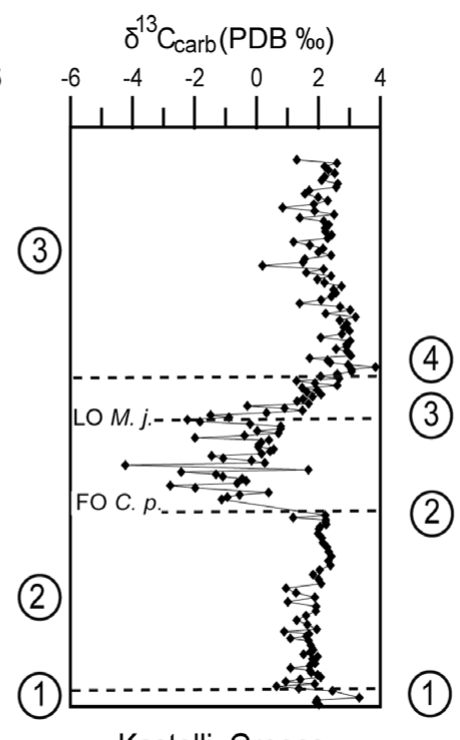

Kastelli, Greece

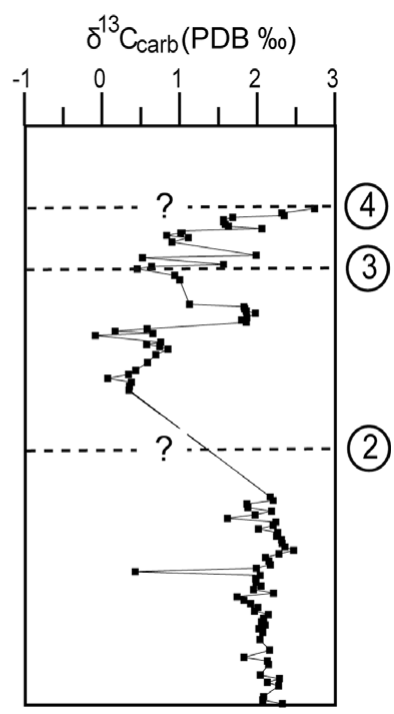

Livartzi, Greece

Figure 9. Comparison between the $\delta^{13} \mathrm{C}_{\text {carb }}$ data from Peniche, Portugal (Hesselbo et al. 2007), Valdorbia, Italy (Sabatino et al. 2009), and Kastelli and Livartzi, Greece. For a colour version of this figure see online Appendix at http://journals.cambridge.org/geo.

\section{6.b. The preservation of the organic matter}

In both stratigraphic sections, the TOC content is very low, especially in Livartzi, where it does not exceed $1 \%$. TOC values in the Toarcian black shales of northern Europe are much higher, rising to $\sim 15 \%$, probably because of relatively elevated organic productivity, a high degree of water mass stratification, local euxinic conditions and lesser water depth (Jenkyns et al. 2002; Sabatino et al. 2009; Jenkyns, 2010). The palaeodepth of the Pindos Ocean was probably greater than that of typical Tethyan continental margins, as preserved in the Alps and the Apennines, and certainly greater than the epicontinental seas of northern Europe. With greater palaeodepths, organic matter would have had a greater transit distance and transit time to the sea floor, thus increasing the chance of oxidation before burial. 6.c. European correlation of the carbon-isotope record and implications for the regional character of the OAE

490

Suggested chemostratigraphic correlations between the Greek sections in the Pindos Zone and other extensively studied sections in Europe are illustrated in Figures 8 and 9. In Figure 8, the correlation is based mostly on the $\delta^{13} \mathrm{C}_{\text {org }}$ data from Yorkshire, Valdorbia, Kastelli and Livartzi, whereas in Figure 9, correlation is based mostly on the $\delta^{13} \mathrm{C}_{\text {carb }}$ data from Peniche, Valdorbia, Kastelli and Livartzi, using the four 'key' levels described by Hesselbo et al. (2007).

In Figure 8, the grey band and the dashed lines in the Yorkshire and Valdorbia profiles are based on $\delta^{13} \mathrm{C}_{\text {org }}$ data and their spectral analyses, whereas the comparison between these two sections and the Greek sections is based only on the shape of the 
carbon-isotope excursion. In all four compared sections, the negative carbon-isotope excursion has a similar range of values, but each profile differs in detail. The Greek sections have a relatively small negative excursion in $\delta^{13} \mathrm{C}_{\text {org }}$ of $\sim-5 \%$, after which values return to background values $(\sim-25 \%$ o). The grey band in the Greek sections marks the extent of the negative carbon-isotope excursion, which covers most, but not all, of the OAE interval, as defined in Yorkshire (Jenkyns, 2010). A suggested correlation between the Kastelli, Valdorbia and Peniche sections (Fig. 9) includes the Pliensbachian/Toarcian excursion (Level 1). Level 1 is not recognizable in the Livartzi section.

In both the Kastelli and Livartzi sections, the positive shift that is marked in Peniche directly above Level 1 is subdued. Level 2 is marked in all sections by the beginning of the negative carbonisotope excursion. In Peniche, Level 2 is located at the polymorphum-levisoni zonal boundary and occurs above the first occurrence (FO) of the nannofossil Carinolithus superbus and Carinolithus poulnabronei (Mailliot et al. 2007). The nannofossil zone of $C$. superbus (referred to as NJT 6) has been suggested to coincide with the OAE (Mattioli et al. 2004). In the Kastelli section, the FO of $C$. poulnabronei, whose first occurrence is stratigraphically very close to that of C. superbus (Mattioli \& Erba, 1999; Mailliot et al. 2007), is located in Level 2, although the lack of carbonate in adjacent parts of the section introduces some stratigraphic uncertainty. Neither the beginning of the negative carbon-isotope excursion nor the NJT 6 Zone is apparent in the Livartzi section; we therefore can only place Level 2 approximately at this location.

Level 3 in Peniche and Valdorbia is where $\delta^{13} \mathrm{C}_{\text {carb }}$ values reach a minimum and thereafter begin to increase. In Peniche, this level corresponds also to the TOC maximum (Hesselbo et al. 2007) whereas, in the other three sections, TOC values have already reached background values at this level. In Peniche, the last occurrence (LO) of Mitrolithus jansae is marked slightly above Level 3 (Mattioli et al. 2008), whereas in Kastelli, it corresponds to Level 3. The top of the section in Peniche is marked as Level 4 and it correlates with the end of the negative excursion and this can also be identified in the Kastelli section, although it is less clear-cut in the Livartzi section.

Although there is some minor diachroneity in nannofossil first and last occurrence datum levels with respect to the $\delta^{13} \mathrm{C}$ record, a striking correlation is documented in this study between the different isotope levels occurring across the negative carbon-isotope excursion in the Kastelli Pelites and other, more fossiliferous ammonite-bearing sections, underscoring the widespread nature of the event (Jenkyns et al. 1985, 2002; Jenkyns \& Clayton, 1986, 1997; Mattioli et al. 2008; Sabatino et al. 2009).

\section{Conclusions}

Integrated chemostratigraphy and biostratigraphy confirm for the first time the age of the Kastelli Pelites of the Pindos Zone in Greece. They were formed during the Early Toarcian OAE and belong to the NJT 6 nannofossil Zone, correlative with the tenuicostatumfalciferum zones of northern Europe or its equivalents in southern Europe (tenuicostatum/polymorphumfalciferum/serpentinum/levisoni zones). The record of the T-OAE from these deep-marine sediments, which were part of the Tethyan Ocean, strongly supports the postulated global character of the T-OAE. The stratigraphic distribution of nannofossils and the shape of the negative carbon-isotope excursion differ from some different European sections, suggesting a degree of regional environmental control and/or diagenetic effects. The carbon-isotope profile from Kastelli resembles that of Valdorbia, Marche-Umbria, Italy (Sabatino et al. 2009), whereas that from Livartzi resembles that of Yorkshire, NE England (Kemp et al. 2005). The small negative excursion in carbon isotopes recently recorded at the Pliensbachian/Toarcian boundary in Peniche, Portugal, in Valdorbia, Italy, the High Atlas of Morocco and in Yorkshire, England, is also identified in the type section of the Kastelli Pelites.

Acknowledgements. The authors would like to thank Dr Norman Charnley (Earth Sciences Department) and Dr Peter Ditchfield (Archaeological Research Laboratory) for isotope analyses performed during a visit of NK to Oxford University. NK would like to thank the European Association of Organic Geochemists for the travel scholarship which she received, and University of Athens SARG for co-funding the field work. EM warmly thanks Mrs Paula Desvignes for help in smear-slide preparation. The reviewers are also thanked for their helpful comments.

\section{References}

Al-Suwaidi, A. H., Angelozzi, G. N., Baudin, F., Damborenea, S. E., Hesselbo, S. P., Jenkyns, H. C., Manceñido, M. O., \& Riccardi, A. C. 2010. First record of the Early Toarcian Oceanic Anoxic Event from the Southern Hemisphere, Neuquén Basin, Argentina. Journal of the Geological Society, London 167, 6336.

Argyriadis, I., De Graciansky, P. C., Marcoux, J. \& RICOU, L. E. 1980. The opening of the Mesozoic Tethys between Eurasia and Arabia-Africa. In Géologie des chaînes alpines issues de la Téthys (eds J. Aubouin, J. Debelmas \& M. Latreille), pp. 199-214. 26th International Geological Congress, Paris, Colloque C5. Bureau de Recherches Géologiques et Minières Mémoire, 115.

AubOUIn, J., BONNEAU, M., DAVIDSON, G. J., LEBOULENGER, P., MAtesko, S. \& Zambetakis, A. 1976. Esquisse structurale de l'Arc égéen externe: des Dinarides aux Taurides. Bulletin de la Societé géologique de France, 7e série 18, 327-36.

BAiley, T. R., Rosenthal, Y., MCARThur, J. M. \& VAN DE SchootbrugGe, B. 2003. Paleoceanographic changes of the Late Pliensbachian-Early Toarcian interval: a possible link to the genesis of an Oceanic Anoxic Event. Earth and Planetary Science Letters 212, 307-20. 
Bernoulli, D., De Graciansky, P. C. D. \& Monod, O. 1974. The extension of the Lycian Nappes (SW Turkey) into the Southeastern Aegean Islands. Eclogae Geologicae Helvetiae 67, 39-90.

Bernoulli, D. \& JenKYnS, H. C. 1974. Alpine, Mediterranean and central Atlantic Mesozoic facies in relation to the early evolution of the Tethys. In Modern and Ancient Geosynclinal Sedimentation (eds R. H. Dott Jr. \& R. H. Shaver), pp. 129-60. Society of Economic Paleontologists and Mineralogists, Special Publication 19.

Bernoulli, D. \& JenKyns, H. C. 2009. Ancient oceans and continental margins of the Alpine-Mediterranean Tethys: deciphering clues from Mesozoic pelagic sediments and ophiolites. Sedimentology 56, 14990 .

BERNOULLI, D. \& RENZ, O. 1970. Jurassic carbonate facies and new ammonite faunas from western Greece. Eclogae Geologicae Helvetiae 65, 573-607.

Bodin, S., Mattioli, E., Fröhlich, S., Marshall, J. D., BOUTIB, L., LAHSINI, S. \& REDFERN, J. 2010. Toarcian carbon isotope shifts and nutrient changes from the Northern margin of Gondwana (High Atlas, Morocco, Jurassic): palaeoenvironmental implications. Palaeogeography, Palaeoclimatology, Palaeoecology 297, doi: 10.1016/j.palaeo.2010.08.018, 377-390

BONNEAU, M. 1982. Evolution géodynamique de l'Arc égéen depuis le Jurassique supérieur jusqu'au Miocène. Bulletin de la Societé géologique de France, 7e série 24, 229-42.

BONNEAU, M. 1984. Correlation of the Hellenide nappes in the south-east Aegean and their tectonic reconstruction. In The geological Evolution of the eastern Mediterranean (eds J. E. Dixon, \& A. H. F. Robertson), pp. 51752. Geological Society of London, Special Publication no. 17.

Bown, P. R. \& Young, J. R. 1998. Chapter 2: techniques. In Calcareous Nannofossil Biostratigraphy (ed. P. R. Bown), pp. 16-28. Dordrecht: Kluwer Academic Publishing.

Bucefalo Palliani, R. \& Mattioli, E. 1998. High resolution integrated microbiostratigraphy of the Lower Jurassic (Late Pliensbachian-Early Toarcian) of Central Italy. Journal of Micropalaeontology 17, 153-72.

Bucefalo Palliani, R., Mattioli, E. \& Riding, J. 2002. The response of marine phytoplankton and sedimentary organic matter to the early Toarcian (Lower Jurassic) oceanic anoxic event in northern England. Marine Micropaleontology 46, 223-45.

Channell, J. E. T. \& KozUR, H. W. 1997. How many oceans? Meliata, Vardar, and Pindos oceans in Mesozoic Alpine paleogeography. Geology 25, 183-6.

CLIFT, P. D. 1992. The collision tectonics of the southern Greek Neotethys. Geologische Rundschau 81, 66979.

DE WeVer, P. 1976. Mise en évidence d'importants affleurements de roches éruptives à la base de la nappe du Pinde-Olonos au sein de la 'Formation à Blocs' (Péloponnése, Gréce). Annales de la Societé Géologique du Nord 97, 123-6.

De Wever, P. \& Baudin, F. 1996. Palaeogeography of radiolarite and organic-rich deposits in Mesozoic Tethys. Geologische Rundschau 85, 310-26.

De Wever, P. \& Origlia-Devos, I. 1982. Datation par les radiolaires des niveaux siliceux du Lias de la Série du Pinde-Olonos (Formation de Drimos, Péloponnèse et Grèce continentale). Comptes Rendus de l'Académie des Sciences, Paris, Série 2 294, 1191-8.
DÉDÉ, S., Cili, P., Bushi, E. \& Makbul, Y. 1976. Traits fondamentaux de la tectonique de Cukal. Permbledhje Studimesh 20/4, 15-33.

Degnan, P. J. \& Robertson, A. H. F. 1998. Mesozoic-early Tertiary passive margin evolution of the Pindos Ocean (NW Peloponnese, Greece). Sedimentary Geology 117, 33-70.

Dercourt, J., Ricou, L. E. \& Vriellynck, B. (eds) 1993. Atlas Tethys Palaeoenvironmental Maps. Paris: Gauthier-Villars, 307 pp.

FleurY, J. J. 1980. Les zones de Gavrovo-Tripolitza et $\mathrm{du}$ Pinde-Olonos (Grèce continentale et Péloponèse du nord). Evolution d'une plate-forme et d'un bassin dans leur cadre alpin. Societé Géologique du Nord, Publication 4, 1-473.

Hermoso, M., Le Callonec, L., Minolatti, F., Renard, M. \& Hesselbo, S. P. 2009. Expression of the Early Toarcian negative carbon-isotope excursion in separated carbonate microfractions (Jurassic, Paris Basin). Earth and Planetary Science Letters 277, 194-203.

Hesselbo, S. P., Gröcke, D. R., JenKyns, H. C., BJerrum, C. J., FArrimond, P., Morgans Bell, H. S. \& Green, O. R. 2000. Massive dissociation of gas hydrate during a Jurassic oceanic anoxic event. Nature 406, 392-5.

Hesselbo, S. P., Jenkyns, H. C., Duarte, L. V. \& OliveIRA, L. C. V. 2007. Carbon-isotope record of the Early Jurassic (Toarcian) Oceanic Anoxic Event from fossil wood and marine carbonate (Lusitanian Basin, Portugal). Earth and Planetary Science Letters 253, 455-70.

JENKYNS, H. C. 1985. The Early Toarcian and CenomanianTuronian anoxic events in Europe: comparisons and contrasts. Geologische Rundschau 74, 505-18.

JENKYNS, H. C. 1988. The early Toarcian (Jurassic) anoxic event: stratigraphic, sedimentary, and geochemical evidence. American Journal of Science 288, 101-51.

JENKYNS, H. C. 2003. Evidence for rapid climate change in the Mesozoic-Palaeogene greenhouse world. Philosophical Transactions of the Royal Society London, Series A 361, 1885-916.

JENKYNS, H. C. 2010. The geochemistry of Oceanic Anoxic Events. Geochemistry, Geophysics, Geosystems 11, Q03004, doi:10.1029/2009GC002788, 30 pp.

Jenkyns, H. C. \& ClaYton, C. J. 1986. Black shales and carbon isotopes in pelagic sediments from the Tethyan Lower Jurassic. Sedimentology 33, 87-106.

Jenkyns, H. C. \& Clayton, C. J. 1997. Lower Jurassic epicontinental carbonates and mudstones from England and Wales: chemostratigraphic signals and the early Toarcian anoxic event. Sedimentology 44, 687-706.

Jenkyns, H. C., Gale, A. S. \& Corfield, R. M. 1994. Carbon- and oxygen-isotope stratigraphy of the English Chalk and Italian Scaglia and its palaeoclimatic significance. Geological Magazine 131, 1-34.

Jenkyns, H. C., GröcKe, D. R. \& Hesselbo, S. P. 2001. Nitrogen isotope evidence for water mass denitrification during the Early Toarcian (Jurassic) Oceanic Anoxic Event. Paleoceanography 16, 593-603.

Jenkyns, H. C., Jones, C. E., Gröcke, D. R., Hesselbo, S. P. \& PARKINSON, D. N. 2002. Chemostratigraphy of the Jurassic System: applications, limitations and implications for palaeoceanography. Journal of the Geological Society, London 159, 351-78.

JenKYns, H. C., MatThews, A., TsiKos, H. \& EREL, Y. 2007. Nitrate reduction, sulfate reduction, and sedimentary iron isotope evolution during the Cenomanian-Turonian oceanic anoxic event. Paleoceanography 22, PA3208, doi: 10.1029/2006PA001355, pp. 17 
Jenkyns, H. C., Sarti, M., Masetti, D. \& Howarth, M. K. 1985. Ammonites and stratigraphy of Lower Jurassic black shales and pelagic limestones from the Belluno Trough, Southern Alps, Italy. Eclogae Geologicae Helvetiae 78, 299-311.

KARAKITSIOS, V. 1995. The influence of preexisting structure and halokinesis on organic matter preservations and thrust system evolution in the Ionian Basin, Northwest Greece. American Association of Petroleum Geologists Bulletin 79, 960-80.

Karakitsios, V., TSiKos, H., VAN Breugel, Y., BaKOPOULOS, I. \& KoletTI, L. 2004. Cretaceous Oceanic Anoxic Events in Western Continental Greece. Bulletin of the Geological Society of Greece 36, 846-55.

Karakitsios, V., Tsikos, H., Van Bruegel, Y., Koletti, L., Sinninghe Damsté, J. S. \& Jenkyns, H. C. 2007. First evidence for the late Cenomanian Oceanic Anoxic Event (OAE2, or 'Bonarelli' event) from the Ionian Zone, western continental Greece. International Journal of Earth Sciences (Geol. Rundsch) 96, 343-52.

Kemp, D. B., Coe, A. L., Cohen, A. S. \& Schwark, L. 2005. Astronomical pacing of methane release in the Early Jurassic period. Nature 437, 396-9.

KÜSPERT, W. 1982. Environmental changes during oil shale deposition as deduced from stable isotope ratios. In Cyclic and Event Stratification (eds G. Einsele \& A. Seilacher), pp. 482-501. Berlin: Springer-Verlag.

Lefèvre, C., Cabanis, B., Ferrière, J., Thiebault, F. \& Platevoet, R. 1993. Mise en évidence d'une dualité dans le volcanisme triasique hellénique: apport de la géochimie des éléments traces. Comptes Rendus de l'Académie des Sciences, Paris, Série 2 316, 1311-18.

LitTLE, C. T. S. \& BeNTON, M. J. 1995. Early Jurassic mass extinction: A global long-term event. Geology 23, 4958.

Littler, K., Hesselbo, S. P. \& Jenkyns, H. C. 2010. A carbon-isotope perturbation at the PliensbachianToarcian boundary: evidence from the Lias Group, NE England. Geological Magazine 147, 181-92.

LyBeris, N., ChOtin, P. \& Doubinger, J. 1980. Précisions stratigraphiques sur la série du Pinde (Grèce): la durée de sédimentation des 'radiolarites'. Comptes Rendus de l'Académie des Sciences, Paris, série D 290, 1513 16.

Mailliot, S., Elmi, S., Mattioli, E. \& Pittet, B. 2007. Calcareous nannofossil assemblages across Pliensbachian/Toarcian boundary at the Peniche section (Ponta do Trovão, Lusitanian Basin). Ciëncias da Terra (Lisbon) 16, 1-14.

Mailliot, S., Mattioli, E., Guex, J. \& Pittet, B. 2006. The Early Toarcian Anoxic Crisis, a synchronous event in the Western Tethys? An approach by Quantitative Biochronology (Unitary Associations), applied on calcareous nannofossils. Palaeogeography, Palaeoclimatology, Palaeoecology 240, 562-86.

Mattioli, E. \& ERBA, E. 1999. Synthesis of calcareous nannofossil events in Tethyan Lower and Middle Jurassic successions. Rivista Italiana di Paleontologia e Stratigrafia 105, 343-76.

Mattioli, E., Pittet, B., Bucefalo Palliani, R., RöHL, H.-J., SCHMID- RÖHL, A., MoretTini, E., MorgansBell, H. S. \& CoHEN, A. S. 2004. Phytoplankton evidence for the timing and correlation of palaeoceanographical changes during the early Toarcian oceanic anoxic event (Early Jurassic). Journal of the Geological Society, London 161, 685-93.

Mattioli, E., Pittet, B., SuAn, G. \& Maillot, S. 2008. Calcareous nannoplankton changes across the early Toarcian oceanic anoxic event in the western Tethys. Paleoceanography 23, PA3208, doi:10.1029/2007PA001435, pp. 17

McArthur, J. M., Donovan, D. T., Thirlwall, M. F., FouKE, B. W. \& MATTEY, D. 2000. Strontium isotope profile of the early Toarcian (Jurassic) oceanic anoxic event, the duration of ammonite biozones, and belemnite palaeotemperatures. Earth and Planetary Science Letters 179, 269-85.

PE-PIPER, G. 1998. The nature of Triassic extension-related magmatism in Greece: evidence from $\mathrm{Nd}$ and $\mathrm{Pb}$ isotope geochemistry. Geological Magazine 135, 331-48.

Pe-PIPER, G. \& HATZIPANAGIOTOU, K. 1993. Ophiolitic rocks of the Kerassies-Milia Belt, continental Greece. Ofioliti 18, 157-69.

RigaKIS, N. \& KARAKITSIOS, V. 1998. The source rock horizons of the Ionian Basin (NW Greece). Marine and Petroleum Geology 15, 593-617.

Robertson, A. H. F., Clift, P. D., Degnan, P. J. \& Jones, G. 1991. Palaeogeographic and palaeotectonic evolution of the Eastern Mediterranean Neotethys. Palaeogeography, Palaeoclimatology, Palaeoecology 87, 289343.

Robertson, A. H. F. \& Karamata, S. 1994. The role of subduction-accretion processes in the tectonic evolution of the Mesozoic Tethys in Serbia. Tectonophysics 234, 73-94.

RÖHL, H.-J., SCHMID-RÖHL, A., OSCHMANN, W., FRIMMEL, A. \& SCHWARK, L. 2001. The Posidonia Shale (Lower Toarcian) of SW-Germany: an oxygen-depleted ecosystem controlled by sea level and palaeoclimate. Palaeogeography, Palaeoclimatology, Palaeoecology 165, 27 52 .

Rosales, I., Robles, S. \& QUeSADA, S. 2004. Elemental and oxygen isotope composition of Early Jurassic belemnites; salinity vs. temperature signals. Journal of Sedimentary Research 74, 342-54.

Sabatino, N., Neri, R., Bellanca, A., Jenkyns, H. C., BAudin, F., PARISI, G. \& MASETTI, D. 2009. Carbonisotope records of the Early Jurassic (Toarcian) oceanic anoxic event from the Valdorbia (Umbria-Marche Apennines) and Monte Mangart (Julian Alps) sections: palaeoceanographic and stratigraphic implications. Sedimentology 56, 1307-28.

Schouten, S., Van KaAm-Peters, H. M. E., Rijpstra, W. I. C., Schoell, M. \& Sinninghe Damsté, J. S. 2000. Effects of an oceanic anoxic event on the stable carbon isotopic composition of Early Toarcian carbon. American Journal of Science 300, 1-22.

SUAN, G., MATTIOLI, Pittet, B., LÉCuYer, C., Suchéras-MarX, B., Duarte, L. V., Philippe, M., Reggiani, L. \& MARTINEAU, F. 2010. Secular environmental precursors to Early Toarcian (Jurassic) extreme climate changes. Earth and Planetary Science Letters 290(3-4), 448-58.

Suan, G., Mattioli, E., Pittet, B., Mailliot, S. \& LECUYER, C. 2008. Evidence for major environmental perturbation prior to and during the Toarcian (Early Jurassic) oceanic anoxic event from the Lusitanian Basin, Portugal. Paleoceanography 23, PA1202, doi: 10.1029/2007PA001459, pp. 14

Svensen, H., Planke, S., Chevallier, L., MaltheSørensen, A. CoRfu, F. \& JAMTVEIT, B. 2007. Hydrothermal venting of greenhouse gases triggering Early Jurassic global warming. Earth and Planetary Science Letters 256, 554-66.

TremoladA, F., VAN DE SchootbrugGe, B. \& ERBA, E. 2005. Early Jurassic schizosphaerellid 
crisis in Cantabria, Spain: Implications for calcification rates and phytoplankton evolution across the Toarcian oceanic anoxic event, Paleoceanography 20, PA2011, doi:10.1029/2004PA001120, pp. 11.

Van Bruegel, Y., BaAs, M., Schouten, S., MattiOLI, E. \& SinNINGHe DAMSTÉ, J. S. 2006. Isorenieratane record in black shales from the Paris Basin, France: Constrains on recycling of respired $\mathrm{CO}_{2}$ as a mechanism for negative carbon isotope shifts during the Toarcian oceanic anoxic event. Paleoceanography 21, PA4220, doi: 10.1029/2006PA001305, pp. 8

VAn de Schootbrugge, B., McArthur, J. M., Bailey, T. R., Rosenthal, Y., Wright, J. D. \& Miller, G. K. 2005. Toarcian oceanic anoxic event: An assessment of global causes using belemnite $\mathrm{C}$ isotope records. Paleoceanography 20, PA3008, doi: 10.1029/2004PA001102, pp. 12
Wignall, P. B., McArthur, J. M., Little, C. T. S. \& HALLAM, A. 2006. Methane release in the Early Jurassic period. Nature 441, E5, doi: 10.1038/nature04905, pp. 1

WignAll, P. B., Newton, R. J. \& Little, C. T. S. 2005. The timing of paleoenvironmental change and cause- $\quad 922$ and-effect relationships during the Early Jurassic mass 923 extinction in Europe. American Journal of Science 305, 924 1014-32.

Woodfine, R. G., Jenkyns, H. C., SARTI, M., BARONCINI, 926 F. \& Violante, C. 2008. The response of two 927 Tethyan carbonate platforms to the early Toarcian 928 (Jurassic) oceanic anoxic event: environmental change 929 and differential subsidence. Sedimentology 55, 1011- 930 28.

Wooler, D. A., Smith, A. G. \& White, N. 1992. Measuring 932 lithospheric stretching on Tethyan passive margins. 933 Journal of the Geological Society, London 149, 517- 934 32.

28

9

